\title{
Pemetrexed versus Gefitinib as Second-line Treatment for Advanced Non-small Cell Lung Cancer: A Meta- analysis Based on Randomized Controlled Trials
}

https://doi.org/10.1515/pteridines-2019-0022

received February 25, 2019; accepted September 30, 2019.

Abstract: Objective To investigate the clinical efficacy and toxicity of Pemetrexed versus Gefitinib as secondline treatment for advanced non-small cell lung cancer (NSCLC). Methods By systematically searching the electronic databases of Pubmed, CENTRAL, Cochrane, EMBASE, ASCO, and CBM, open published randomized clinical trials (RCTs) relevant to clinical efficacy and toxicity of Pemetrexed versus Gefitinib as second-line treatment of advanced NSCLC were included in the meta-analysis. Data of objective response rate (ORR) and drug related toxicity were extracted from the original publications and pooled by random or fixed effect method. Results Fourteen clinical trials related to Pemetrexed versus Gefitinib as second-line treatment for advanced NSCLC fulfilled the inclusion criteria and were included in the meta-analysis. The pooled results show that the ORR ( $\mathrm{RR}=0.81,95 \% \mathrm{CI}: 0.56-1.16, \mathrm{p}=0.25)$ and $\mathrm{DCR}(\mathrm{RR}=1.11$, 95\% CI:0.94-1.31, $\mathrm{p}=0.24$ ) were not statistical different for Pemetrexed versus Gefitinib as second-line treatment of advanced NSCLC. However, the pooled data demonstrated the risk of developing skin rash $(\mathrm{RR}=0.10,95 \% \mathrm{CI}: 0.03-$ $0.30, \mathrm{p}=0.00)$ and diarrhea $(\mathrm{RR}=0.31,95 \% \mathrm{CI}: 0.15-0.67$, $\mathrm{p}=0.003$ ) in patients with Pemetrexed was significantly lower than that of Gefitinib through random effect model analysis, but the incidence of neutropenia in Pemetrexed group was significantly higher than that of Gefitinib with statistical difference ( $R R=7.62,95 \%$ CI:3.71-15.66, $p=0.00$ ). Conclusion Pemetrexed was not inferior as second-line

\footnotetext{
*Corresponding author: Handi Lv, Department of Respiratory, Zhuji Affiliated Hospital of Shaoxing University Zhejiang Province 311800 PR China, E-mail: 942357059@qq.com

Huiyu Wang, Feng Liu, Department of Pharmacy, Traditional Chinese Medicine Hospital of Lishui, Zhejiang Province, 323000 PR China Zunjing Zhang, Department of Infection, Traditional Chinese Medicine Hospital of Lishui, Zhejiang Province, 323000 PR China

Miaoying Zhou, Department of Pharmacy, Longquan People's Hospital, Zhejiang Province, 323700 PR China
}

treatment for advanced NSCLC compared to Gefitinib for tumor response. However, Pemetrexed had higher incidence of neutropenia but lower risk of developing skin rash and diarrhea.

Keywords: Pemetrexed; Gefitinib; Non-small Cell Lung Cancer; Meta-analysis.

\section{Introduction}

Lung cancer (including non-small cell lung cancer and small cell lung cancer) is the most diagnosed malignant carcinoma for males and females word-wide, and is the leading cause of cancer related death for men and the second for women [1]. Non-small cell lung cancer (NSCLC) is a main type of lung cancer, accounting for about $80 \%$ of all type lung cancers. About $75 \%$ of NSCLC were at advanced or locally advanced metastatic stage when first diagnosis and lost the opportunity for operation [2]. For these advanced stage NSCLC patients, a platinum based two-drug combination chemotherapy regimen is the first-line chemotherapy and is recommended by the National Comprehensive Cancer Network (NCCN). Compared to best supportive care, platinum based twodrug chemotherapy can improve the overall survival and progression free survival (PFS) [3, 4]. However, most of the patients developed drug resistance after several cycles of platinum based first-line chemotherapy. A second-line chemotherapy was recommended for these patients with good performance status [5]. The second-line chemotherapy drugs includes Docetaxel, Pemetrexed, and small molecule tyrosine kinase receptor inhibitors (epidermal growth factor receptors) tyrosine kinase inhibitor (EGFR-TKI) Gefitinib and Erlotinib [6-9]. Pemetrexed is a new-generation antifolate agent, approved for the treatment of mesothelioma and NSCLC. Pemetrexed works by disrupting folate-dependent metabolic processes which are essential for cancer 
cell replication and survival. Previously published randomized clinical trials have compared the efficacy and toxicity of Pemetrexed versus Gefitinib as secondline treatment for advanced NSCLC [10-12]. However, the results were not conclusive because of small sample sizes with limited statistical power. Therefore, in our present work we investigate the clinical efficacy and toxicity of Pemetrexed versus Gefitinib as second-line treatment for advanced NSCLC in order to provide more information for clinical use of these two drugs.

\section{Material and Methods}

\section{Publication electronic searching}

The randomized clinical trials (RCTs) systematic electronic searching process was performed according to the PRISMA (Preferred Reporting Items for Systematic Reviews and Meta-Analyses) statement flow chart (Figure 1). Prospective RCTs related to Pemetrexed versus Gefitinib as second-line treatment for advanced NSCLC published before January 2019 were screened in the electronic databases of Pubmed, CENTRAL, Cochrane, EMBASE, ASCO, and CBM. The electronic searching text words were: non-small cell lung cancer/NSCLC, Gefitinib, Iressa. The publication search was restricted to human beings and with the language restriction of English and Chinese.

\section{Publication inclusion and exclusion criteria}

The studies were screened and included based on publication type, patients, treatment, and outcomes. The included publications fulfilled the following requirements: (i) Prospective randomized controlled trials. (ii) The subjects included in each individual study should be limited to NSCLC with advance stage and previous chemotherapy treatment. (iii) The second-line chemotherapy restricted to Pemetrexed versus Gefitinib. (iv) The objective response rate (ORR), disease control rate (DCR), and chemotherapy related toxicity were proved in the original included studies. (v). Studies published in Chinese or English. The publication with the following features were excluded: (i) Retrospective clinical observation. (ii) Small cell lung cancer. (iii) Patients received previously chemotherapy of Pemetrexed or Gefitinib. (iv) Duplicated publication or data. Publication searching and inclusion was performed by two reviewers independently and discussed when disagreement was encounter.

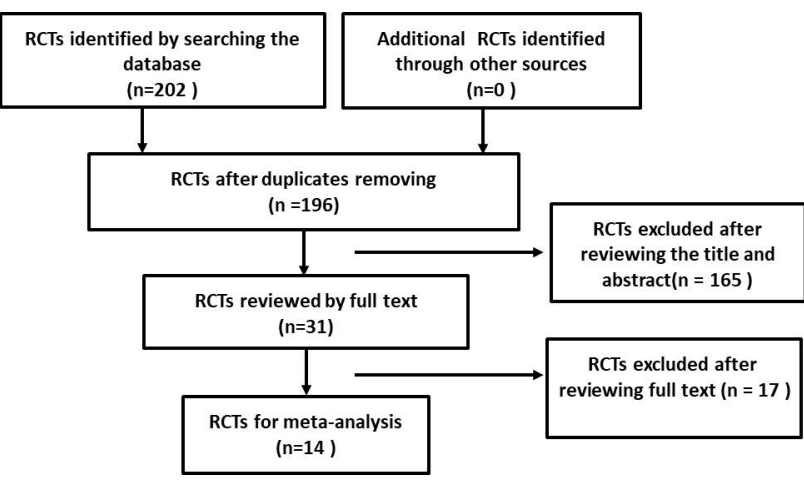

Figure 1: The publication searching follow chart according to preferred reporting items for systematic reviews and meta-analyses

\section{Data extraction}

The data was extracted by two reviewers independently. A data extraction table was prepared before extracting the data. The table includes author name, journal of the publication, publication year, dosage of Pemetrexed or Gefitinib, age of the subject, and outcomes (ORR, DCR, skin rash, diarrhea, and neutropenia).

\section{Statistical analysis}

Stata 11.0 statistical software was used to analysis the data. The dichotomous data ORR, DCR, frequency of skin rash, diarrhea, and neutropenia is shown as risk ratio (RR) when comparing Pemetrexed and Gefitinib. A RR 1 indicates a low risk of ORR, DCR, skin rash, diarrhea, and neutropenia. Before pooling the data, we first evaluated the statistical heterogeneity through the $\mathrm{I}^{2}$ test. If $\mathrm{I}^{2} \mathrm{~g} 50 \%$, the statistical heterogeneity was significant and the data was pooled by random-effect method. Inversely, if there was no significant heterogeneity, the fixed-effect method was sued.

\section{Results}

\section{Main characters of the included 14 trials}

Fourteen clinical trials [10-23] related to Pemetrexed versus Gefitinib as second-line treatment for advanced NSCLC fulfilled the inclusion criteria and were included in the meta-analysis. The main characteristics of the included publication are demonstrated in Table 1. 
Table 1: Main characters of the included 14 trials.

\begin{tabular}{|c|c|c|c|c|}
\hline Trials(year) & $\begin{array}{l}\text { No. of patients } \\
\text { (Pemetrexed/ } \\
\text { Gefitinib) }\end{array}$ & $\begin{array}{l}\operatorname{Age}(P / G) \\
\min -\max \end{array}$ & Administration of Pemetrexed & Administration of Gefitinib \\
\hline Zhang(2009) & $32 / 35$ & $41-76 / 42-78$ & $\begin{array}{l}\text { Pemetrexed } 500 \mathrm{mg} / \mathrm{m}^{2}+0.9 \% \text { NS } 100 \mathrm{~mL} \text {, IV drip } \\
\text { more than } 10 \text { minutes, once every } 3 \text { weeks }\end{array}$ & $\begin{array}{l}\text { Gefitinib } 250 \mathrm{mg} / \text { day, qd } \\
\text { orally }\end{array}$ \\
\hline Hong(2010) & $20 / 20$ & $38-74 / 43-73$ & $\begin{array}{l}500 \mathrm{mg} / \mathrm{m}^{2} \text { of pemetrexed mixed with } 100 \mathrm{~mL} \text { of } \\
\text { normal saline as a } 10 \text { minute intravenous infusion } \\
\text { on day } 1 \text { every } 3 \text { weeks. }\end{array}$ & $\begin{array}{l}\text { Gefitinib } 250 \text { mg per daily } \\
\text { orally }\end{array}$ \\
\hline Sun(2012) & $67 / 68$ & $30-78 / 40-77$ & $\begin{array}{l}\text { Pemetrexed } 500 \mathrm{mg} / \mathrm{m}^{2} \mathrm{IV} \text { drip more than } 10 \\
\text { minutes, once every } 3 \text { weeks }\end{array}$ & $\begin{array}{l}\text { Gefitinib } 250 \mathrm{mg} / \text { day, qd } \\
\text { orally }\end{array}$ \\
\hline Zhang(2012) & $40 / 40$ & NR & $\begin{array}{l}\text { Pemetrexed } 500 \mathrm{mg} / \mathrm{m}^{2} \mathrm{IV} \text { drip more than } 10 \\
\text { minutes, once every } 3 \text { weeks }\end{array}$ & $\begin{array}{l}\text { Gefitinib } 250 \mathrm{mg} / \text { day, qd } \\
\text { orally }\end{array}$ \\
\hline Wang(2012) & $23 / 23$ & $63.3 / 64.2$ & $\begin{array}{l}\text { Pemetrexed } 500 \mathrm{mg} / \mathrm{m}^{2}+0.9 \% \mathrm{NS} 100 \mathrm{~mL} \text {, IV drip } \\
\text { more than } 10 \text { minutes, once every } 3 \text { weeks }\end{array}$ & $\begin{array}{l}\text { Gefitinib } 250 \mathrm{mg} / \text { day, qd } \\
\text { orally }\end{array}$ \\
\hline Dai(2013) & $23 / 23$ & $47-72 / 41-74$ & $\begin{array}{l}\text { Pemetrexed } 500 \mathrm{mg} / \mathrm{m}^{2} \mathrm{IV} \text { drip more than } 10 \\
\text { minutes, once every } 3 \text { weeks }\end{array}$ & $\begin{array}{l}\text { Gefitinib } 250 \mathrm{mg} / \text { day, qd } \\
\text { orally }\end{array}$ \\
\hline Zhao HL(2013) & $38 / 37$ & NR & $\begin{array}{l}\text { Pemetrexed } 500 \mathrm{mg} / \mathrm{m}^{2}+0.9 \% \mathrm{NS} 100 \mathrm{~mL} \text {, IV drip } \\
\text { more than } 10 \text { minutes, once every } 3 \text { weeks }\end{array}$ & $\begin{array}{l}\text { Gefitinib } 250 \mathrm{mg} / \text { day, qd } \\
\text { orally }\end{array}$ \\
\hline Zhou(2014) & $76 / 81$ & $24-75 / 27-78$ & $\begin{array}{l}\text { Pemetrexed } 500 \mathrm{mg} / \mathrm{m}^{2} \mathrm{IV} \text { drip more than } 10 \\
\text { minutes, once every } 3 \text { weeks }\end{array}$ & $\begin{array}{l}\text { Gefitinib } 250 \mathrm{mg} / \text { day, qd } \\
\text { orally }\end{array}$ \\
\hline $\operatorname{Liu}(2015)$ & $22 / 20$ & $61.33 / 62.31$ & $\begin{array}{l}\text { Pemetrexed } 500 \mathrm{mg} / \mathrm{m}^{2} \mathrm{IV} \text { drip more than } 10 \\
\text { minutes, once every } 3 \text { weeks }\end{array}$ & $\begin{array}{l}\text { Gefitinib } 250 \mathrm{mg} / \text { day, qd } \\
\text { orally }\end{array}$ \\
\hline Zhu(2015) & $60 / 60$ & $54.9 / 55.7$ & $\begin{array}{l}\text { Pemetrexed } 500 \mathrm{mg} / \mathrm{m}^{2} \mathrm{IV} \text { drip more than } 10 \\
\text { minutes, once every } 3 \text { weeks }\end{array}$ & $\begin{array}{l}\text { Gefitinib } 250 \mathrm{mg} / \text { day, qd } \\
\text { orally }\end{array}$ \\
\hline $\mathrm{Xu}(2015)$ & $94 / 94$ & $\begin{array}{l}62-82 \text { (two } \\
\text { groups) }\end{array}$ & $\begin{array}{l}\text { Pemetrexed } 500 \mathrm{mg} / \mathrm{m}^{2}+0.9 \% \mathrm{NS} 100 \mathrm{~mL} \text {, IV drip } \\
\text { more than } 10 \text { minutes, once every } 3 \text { weeks }\end{array}$ & $\begin{array}{l}250 \text { mg gefitinib at night } \\
\text { in the first day and in the } \\
\text { morning after that day. } 21 \mathrm{~d} \\
\text { for a course of treatment. }\end{array}$ \\
\hline Zhang(2016) & $55 / 50$ & $\mathrm{NR}$ & $\begin{array}{l}\text { Pemetrexed } 500 \mathrm{mg} / \mathrm{m}^{2}+0.9 \% \mathrm{NS} 100 \mathrm{~mL} \text {, IV drip } \\
\text { more than } 10 \text { minutes, once every } 3 \text { weeks }\end{array}$ & $\begin{array}{l}\text { Gefitinib } 250 \mathrm{mg} / \text { day, qd } \\
\text { orally }\end{array}$ \\
\hline $\operatorname{Lin}(2016)$ & $48 / 53$ & $36-78 / 35-77$ & $\begin{array}{l}\text { Pemetrexed } 500 \mathrm{mg} / \mathrm{m} 2 \text { intravenous infusion for } \\
10 \text { minutes on day } 1 \text {, every } 3 \text { weeks }\end{array}$ & Gefitinib $250 \mathrm{mg} /$ day, orally \\
\hline $\operatorname{Kim}(2016)$ & $47 / 48$ & $31-81 / 42-82$ & $\begin{array}{l}\text { Pemetrexed } 500 \mathrm{mg} / \mathrm{m}^{2} \mathrm{IV} \text { drip more than } 10 \\
\text { minutes, once every } 3 \text { weeks }\end{array}$ & $\begin{array}{l}\text { Gefitinib } 250 \mathrm{mg} / \text { day, qd } \\
\text { orally }\end{array}$ \\
\hline
\end{tabular}

$\mathrm{P}=$

$\mathrm{G}=$

\section{Pooled objective response rate and disease control rate}

$\mathrm{I}^{2}$ test indicated there was significant statistical heterogeneity for the ORR and DCR. Therefore, the data were pooled by random effect model. The pooled results showed the ORR (RR=0.81, 95\% CI:0.56-1.16, $\mathrm{p}=0.25$ ) (Figure 2) and DCR (RR=1.11, 95\% CI:0.94-1.31, $\mathrm{p}=0.24$ ) (Figure 3) were not statistical different of Pemetrexed versus Gefitinib as second-line treatment for advanced NSCLC.

\section{Pooled drug related toxicity}

The drug related toxity inclued skin rash, diarrhea, and neutropenia. Study numbers 10, 13 and 8 reported the incidence of skin rash, diarrhea, and neutropenia respectivley. Significant statisticla heterogeniety was found in skin rash and diarrhea $(\mathrm{p}<0.05)$, but not neutropenia ( $p>0.05)$. The pooled results showed that the risk of developing skin rash ( $\mathrm{RR}=0.10,95 \% \mathrm{CI}: 0.03-$ $0.30, \mathrm{p}=0.00)$ (Figure 4) and diarrhea $(\mathrm{RR}=0.31,95 \%$ 


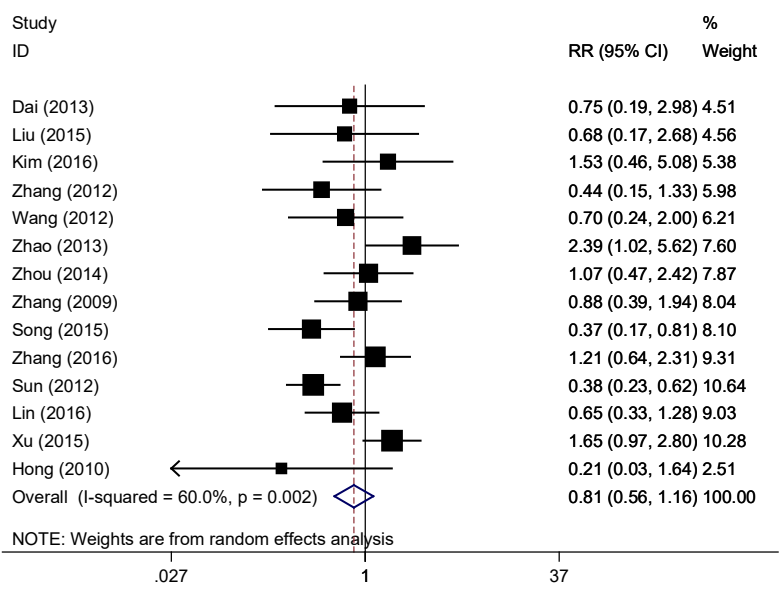

Figure 2: Forest of ORR of Pemetrexed versus Gefitinib as secondline treatment for advanced NSCLC.

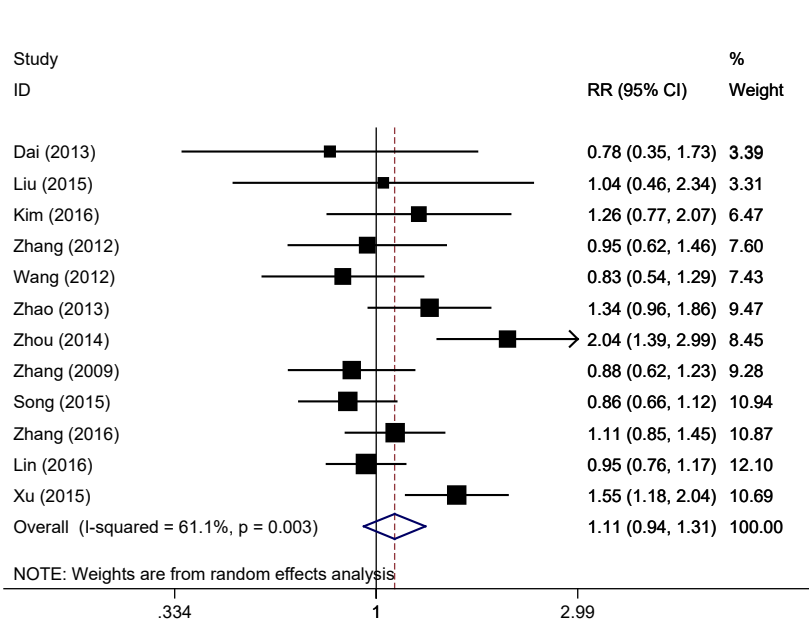

Figure 3: Forest of DCR of Pemetrexed versus Gefitinib as secondline treatment for advanced NSCLC.

CI:0.15-0.67, $\mathrm{p}=0.003$ ) (Figure 5) in the Pemetrexed group was significant lower than that of the Gefitinib group, as determined through random effect model analysis. However, the incidence of neutropenia in the Pemetrexed group was significantly higher than that of the Gefitinib with statistical difference ( $R R=7.62,95 \%$ CI:3.71-15.66, $\mathrm{p}=0.00$ ), Figure 6 .

\section{Publication bias}

The publication bias of Pemetrexed versus Gefitinib as second-line treatment for advanced NSCLC was assessed through Begg's funnel plot. The plot has general left and right symmetrical which indicates no significant publication bias, Figure 7.

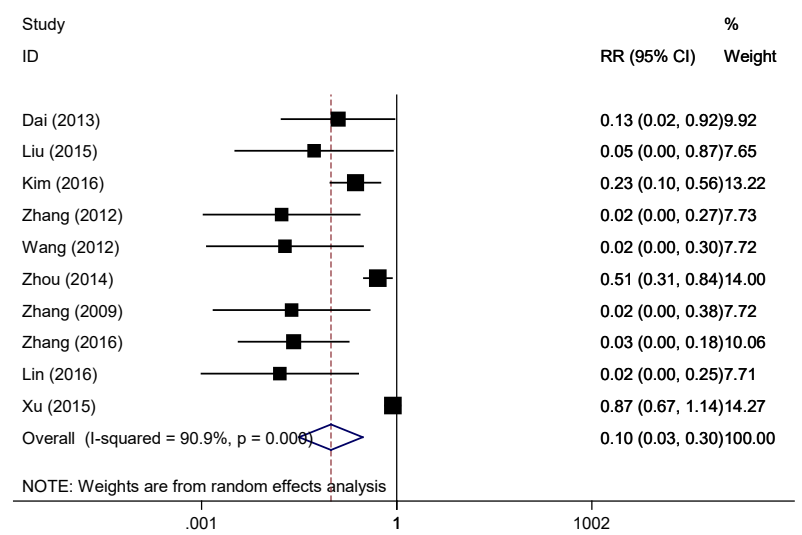

Figure 4: Forest of skin rash of Pemetrexed versus Gefitinib as second-line treatment for advanced NSCLC.

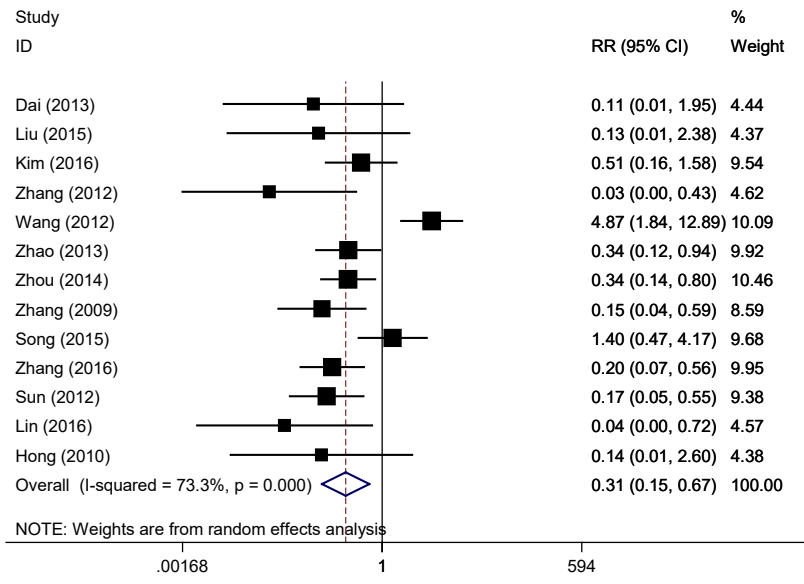

Figure 5: Forest of diarrhea of Pemetrexed versus Gefitinib as second-line treatment for advanced NSCLC.

\section{Discussion}

Epidemiology studies have demonstrated that NSCLC has become the leading cause of cancer related death wordwide. However, most of the cases were at advance stages and must receive chemotherapy as the main treatment method. Pemetrexed was the most clinical used drug for second line chemotherapy of NSCLC. In 2004, the Food and Drug Administration (FDA) of the United States approved Pemetrexed as the second-line for the treatment of locally advanced or metastatic NSCLC in patients with non-squamous histology [24, 25]. Prospective randomized clinical phase III trials proved that Pemetrexed maintenance chemotherapy can improve the prognosis of patients with advance non-squamous cell NSCLC [4]. The tumor inhibiting activity of Pemetrexed works by inhibiting three enzymes used in purine and pyrimidine synthesis, thymidylate synthase (TS), dihydrofolate 


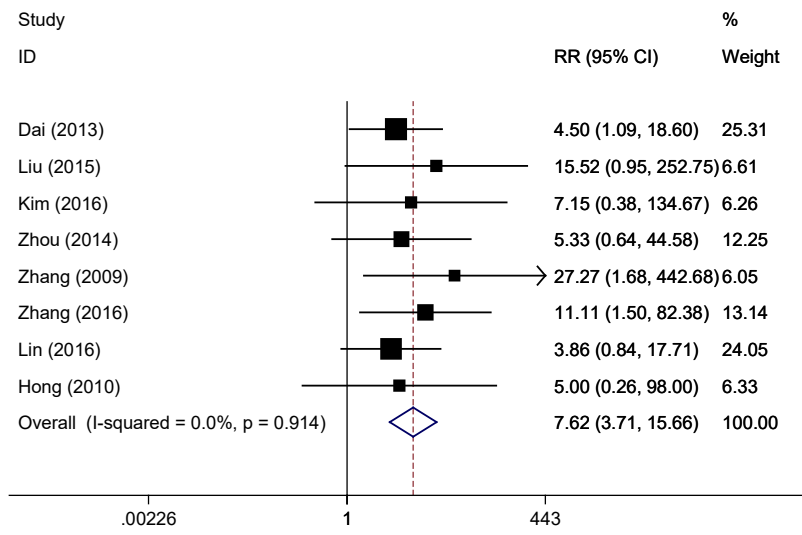

Figure 6: Forest of neutropenia of Pemetrexed versus Gefitinib as second-line treatment for advanced NSCLC.

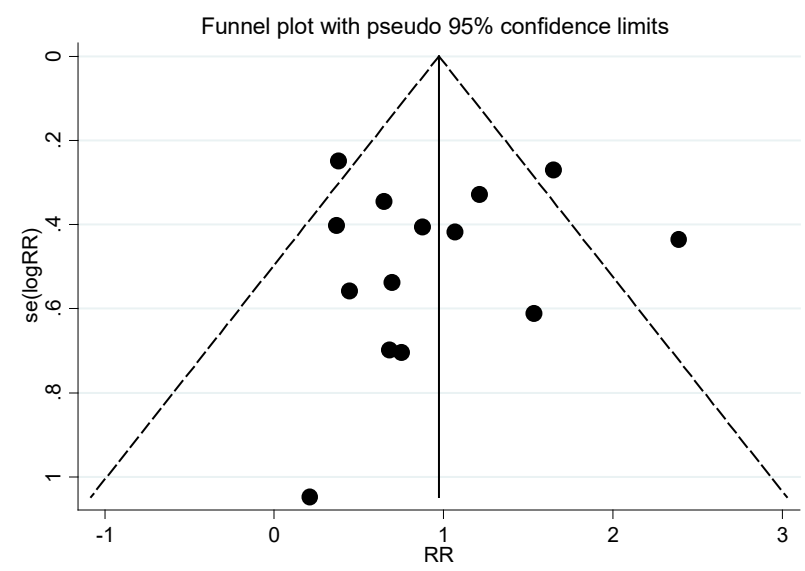

Figure 7: Begg's funnel plot and corresponding $95 \% \mathrm{Cl}$ for Pemetrexed versus Gefitinib as second-line treatment for advanced NSCLC.

reductase (DHFR), and glycinamide ribonucleotide formyltransferase (GARFT) [26-28].

Several prospective studies have demonstrated that Pemetrexed has good tumor response rate and less chemotherapy related toxicity as the second-line chemotherapy for advanced NSCLC. Gefitinib is the first selective inhibitor of epidermal growth factor receptor's (EGFR) tyrosine kinase domain which was approved by the FDA for the treatment of patients with locally advanced or metastatic NSCLC after failure of both platinum-based and Docetaxel chemotherapies [29, 30]. A large-scale, double-blinded prospective randomized clinical trial (IRESSA Pan-Asia Study, IPASS) [31] comparing Gefitinib versus carboplatin/paclitaxel in treatment of advanced NSCLC was published in The New England Journal of Medicine in 2009, and showed the PFS was significantly longer for Gefitinib than chemotherapy in patients with EGFR mutation positive tumors. However, the PFS was significantly longer for chemotherapy than Gefitinib in patients without EGFR mutation.

However, the clinical treatment response and drug related toxicity of Pemetrexed versus Gefitinib as secondline treatment for advanced NSCLC was not clear although several studies had investigated this topic. In our present work, we performed a meta-analysis by pooling the data from 14 openly published studies. The combined results show that Pemetrexed is not inferior as second-line treatment for advanced NSCLC compared to Gefitinib for tumor response. However, Pemetrexed has higher incidence of neutropenia but lower risk of developing skin rash and diarrhea. In the clinical practices, the cancer tissue could not be obtained in all the advance NSCLC patients. Therefore, the EGFR mutation status was not clear for a large part of the patients. For the patients with unknown EGFR status, Pemetrexed was a rational selection as a second-line chemotherapy.

Our work demonstrated that Pemetrexed was not inferior as second-line treatment for advanced NSCLC compared to Gefitinib in tumor response. However, Pemetrexed had higher incidence of neutropenia but lower risk of developing skin rash and diarrhea. Our work also has limitations: (i) Only 14 clincal trials were included in the meta-analysis, the sample size is relative small. (ii) Significant statistical heterogeneity for the ORR and DCR existed, which may decrease the statistical power. (iii) Only studies published in English or Chinsese were inlcuded. Therefor, the conclusion of this work needs further verification by well designed RCTs or high quality individual meta-analysis.

Conflict of interest: Authors state no conflict of interest.

\section{References}

1. Cao M, Chen W. Epidemiology of lung cancer in China. Thorac Cancer 2019;10:3-7.

2. Jia B, Zheng Q, Qi X, Zhao J, Wu M, An T, et al. Survival comparison of right and left side non-small cell lung cancer in stage I-IIIA patients: A Surveillance Epidemiology and End Results (SEER) analysis. Thorac Cancer 2019.

3. Maneechawakajorn J, Hathaisanguan S. Quality of Life Achieved by Carboplatin Plus Etoposide as Third-Line Chemotherapy Compared with Best Supportive Care in NonSmall Cell Lung Cancer Stage IIIB/IV. J Med Assoc Thai 2016;99 Suppl 2:S175-81.

4. Zhi C, Yukun Q, Haizhu C, Shuping L, Ke Z, Huaqing W. Serum Homocysteine and Vitamin B12 as Biomarkers for 
Haematological Toxicity in Lung Adenocarcinoma Treated With Pemetrexed. Pteridines 2019;30:107-113. .

5. Zhou S, Zuo L, He X, Pi J, Jin J, Shi Y. Efficacy and safety of rh-endostatin (Endostar) combined with pemetrexed/cisplatin followed by rh-endostatin plus pemetrexed maintenance in non-small cell lung cancer: A retrospective comparison with standard chemotherapy. Thorac Cancer 2018;9:1354-1360.

6. Liu Z, Wei Z, Hu Y, Gao F, Hao L, Fang P, et al. A phase II open-label clinical study of comparing nab-paclitaxel with pemetrexed as second-line chemotherapy for patients with stage IIIB/IV non-small-cell lung cancer. Med Oncol 2015;32:216.

7. Ellis PM, Leighl NB, Hirsh V, Reaume MN, Blais N, Wierzbicki $R$, et al. A Randomized, Open-Label Phase II Trial of Volasertib as Monotherapy and in Combination With Standard-Dose Pemetrexed Compared With Pemetrexed Monotherapy in Second-Line Treatment for Non-Small-Cell Lung Cancer. Clin Lung Cancer 2015;16:457-65.

8. Park S, Keam B, Kim SH, Kim KH, Kim YJ, Kim JS, et al. Pemetrexed Singlet Versus Nonpemetrexed-Based Platinum Doublet as Second-Line Chemotherapy after First-Line Epidermal Growth Factor Receptor (EGFR) Tyrosine Kinase Inhibitor Failure in Non-small Cell Lung Cancer Patients with EGFR Mutations. Cancer Res Treat 2015;47:630-7.

9. Lee DH, Lee JS, Wang J, Hsia TC, Wang X, Kim J, et al. Pemetrexed-Erlotinib, Pemetrexed Alone, or Erlotinib Alone as Second-Line Treatment for East Asian and Non-East Asian Never-Smokers with Locally Advanced or Metastatic Nonsquamous Non-small Cell Lung Cancer: Exploratory Subgroup Analysis of a Phase II Trial. Cancer Res Treat 2015;47:616-29.

10. Zhang YH, Wang HB. Comparison of clinical efficacy on gefitinib vs pemetrexed as a non-small cell lung cancer who had failed to first-line treatment. Chinese Journal Of Clinical Rational Drug Use 2009;2:14-16.

11. Hong J, Kyung SY, Lee SP, Park JW, Jung SH, Lee JI, et al. Pemetrexed versus gefitinib versus erlotinib in previously treated patients with non-small cell lung cancer. Korean J Intern Med 2010;25:294-300.

12. Wang MQ, He LX, Peng DW, Jiang SQ, Cheng XZ, Xie ZM. Comparison of efficacy of pemetrexed and gefitinib as secondline therapy in treatment of patients with advanced non small cell lung cancer. China Tropical Medicine 2012;12:1361-1363.

13. Zhang J, Liu SQ, Zhang J, Ban LY, Zhou T. Effect and cost-efficacy analysis of the second-line treatment of advanced non-small cell lung cancer. Chin Clin Oncol 2012;17:908-911.

14. Sun JM, Lee KH, Kim SW, Lee DH, Min YJ, Yun HJ, et al. Gefitinib versus pemetrexed as second-line treatment in patients with nonsmall cell lung cancer previously treated with platinumbased chemotherapy (KCSG-LU08-01): an open-label, phase 3 trial. Cancer 2012;118:6234-42.

15. Zhao LH, Wang HY, Zhang DF. Efficacy comparison of Pemetrexed and gefitinib as second line treatment for advanced non-small cell lung cancer. Chin J Clin Oncol Rehabil 2013;20:1235-1238.

16. Dai H, Xu L, Xia C, Chen W. A randomized clinical study of Gefitinib and pemetrexed as second line therapy for advanced non-squamous non-small cell lung cancer. Zhongguo Fei Ai Za Zhi 2013;16:405-10.
17. Zhou Q, Cheng Y, Yang JJ, Zhao MF, Zhang L, Zhang XC, et al. Pemetrexed versus gefitinib as a second-line treatment in advanced nonsquamous nonsmall-cell lung cancer patients harboring wild-type EGFR (CTONG0806): a multicenter randomized trial. Ann Oncol 2014;25:2385-91.

18. Liu XM. Clinical efficacy and safety of gefitinib versus pemetrexed second line treatment of non-small cell lung cancer. The Chinese Journal of Clinical Pharmacology 2015:2393-2395.

19. Xu YH, Mei JS, Zhou J. Randomized study of gefitinib versus pemetrexed as maintenance treatment in patients with advanced glandular non-small cell lung cancer. Int J Clin Exp Med 2015;8:6242-6.

20. Song TT, Gai HR, Li W, Fangjuan H. Therapeutic effect of gefitinib in patients with later period non-small cell lung cancer. Chinese Journal of Difficult and Complicated Cases 2015:778-781.

21. Zhang DG, Ruan XL. A randomized clinical study of gefitinib and pemetrexed as second line therapy for advanced non-small cell lung cancer. Oncology Progress 2016;14:78-80,86.

22. Lin L, Zhao J, Hu J, Huang F, Han J, He Y, Cao X. Comparison of the efficacy and tolerability of gefitinib with pemetrexed maintenance after first-line platinum-based doublet chemotherapy in advanced lung adenocarcinoma: singlecenter experience. Onco Targets Ther 2016;9:6305-6314.

23. Kim YS, Cho EK, Woo HS, Hong J, Ahn HK, Park I, et al. Randomized Phase II Study of Pemetrexed Versus Gefitinib in Previously Treated Patients with Advanced Non-small Cell Lung Cancer. Cancer Res Treat 2016;48:80-7.

24. Hazarika M, White RM, Johnson JR, Pazdur R. FDA drug approval summaries: pemetrexed (Alimta). Oncologist 2004;9:482-8.

25. Cohen MH, Johnson JR, Wang YC, Sridhara R, Pazdur R. FDA drug approval summary: pemetrexed for injection (Alimta) for the treatment of non-small cell lung cancer. Oncologist 2005;10:363-8.

26. Shimizu T, Nakanishi Y, Nakagawa Y, Tsujino I, Takahashi $\mathrm{N}$, Nemoto $\mathrm{N}$, et al. Association between expression of thymidylate synthase, dihydrofolate reductase, and glycinamide ribonucleotide formyltransferase and efficacy of pemetrexed in advanced non-small cell lung cancer. Anticancer Res 2012;32:4589-96.

27. Chen CY, Chang YL, Shih JY, Lin JW, Chen KY, Yang CH, et al. Thymidylate synthase and dihydrofolate reductase expression in non-small cell lung carcinoma: the association with treatment efficacy of pemetrexed. Lung Cancer 2011;74:132-8.

28. Capiaux GM, Budak-Alpdogan T, Alpdogan O, Bornmann W, Takebe N, Banerjee D, et al. Protection of hematopoietic stem cells from pemetrexed toxicity by retroviral gene transfer with a mutant dihydrofolate reductase-mutant thymidylate synthase fusion gene. Cancer Gene Ther 2004;11:767-73.

29. Kazandjian D, Blumenthal GM, Yuan W, He K, Keegan P, Pazdur R. FDA Approval of Gefitinib for the Treatment of Patients with Metastatic EGFR Mutation-Positive Non-Small Cell Lung Cancer. Clin Cancer Res 2016;22:1307-12.

30. Cohen MH, Williams GA, Sridhara R, Chen G, Pazdur R. FDA drug approval summary: gefitinib (ZD1839) (Iressa) tablets. Oncologist 2003;8:303-6.

31. Mok TS, Wu YL, Thongprasert S, Yang CH, Chu DT, et al. Gefitinib or carboplatin-paclitaxel in pulmonary adenocarcinoma. N Engl J Med 2009;361:947-57. 